\title{
An investigation of the effects of ethno-religious conflicts on security in Taraba State, Nigeria, 1991-2020
}

\author{
Atando D. Agbu ${ }^{1 \star}$, Elijah I. Akombo ${ }^{1}$ and Ruth S. Agbu \\ 1Department of History \& Diplomatic Studies, Taraba State University, Jalingo, Nigeria. \\ ${ }^{2}$ Department of History \& Diplomatic Studies, Federal University, Wukari, Nigeria. \\ *Corresponding author. Email: atandodauda@tsuniversity.edu.ng; Tel: +234 8032726238.
}

Copyright @ 2021 Agbu et al. This article remains permanently open access under the terms of the Creative Commons Attribution License 4.0, which permits unrestricted use, distribution, and reproduction in any medium, provided the original work is properly cited.

Received 15th June, 2021; Accepted 12th July, 2021

\begin{abstract}
Since independence, Nigeria has been experiencing high level of violence, crime and criminality in all geopolitical zones, posing great threat to national security, and social, political and economic development. Such disturbing phenomena include the political crises of the First Republic; the religious crisis of the 1980s; the ethno-religious crises of the post-1999 era; the activities of Oodua People's Congress (OPC) and Bakassi boys; the Niger-Delta crisis; to the insurgency in the North-Eastern region and armed-herdsmen violence, particularly in the Middle-Belt region. All these phenomena have created disturbing security challenges to the peoples of the immediate environments of the incidents, and the whole nation, thus affecting nation-building. This paper adopts a multi-disciplinary approach, examines the security challenges posed by ethno-religious conflicts, particularly in Taraba State of Nigeria. The research interrogates the challenges posed by the phenomena mentioned, and finds, among other things, that in the past 60 years, the incidents have significantly contributed to the slow pace of social, political and economic developments in the area. The paper suggests, among other things, tolerance and responsive governance, to curtail envisaged security challenges facing Taraba State, and Nigeria in general.
\end{abstract}

Keywords: Crime, criminality, crisis, ethnic, insecurity, religion, violence.

\section{INTRODUCTION}

Nigeria is a multi-ethnic country with more than 250 ethnic groups, and by far the most populated country in the whole of Africa with an estimated population of $206,139,582$ in 2020 (Worldometers.info, 2020). It is also a multi-religious nation with Islam and Christianity as the two main religions. The nation comprises of 36 States, a Federal Capital Territory (FCT), 774 Local Government Councils, and with a complex ethno-religious composition (Oyeniyi, 2012). According to Tella (2015), although Nigeria's Gross Domestic Product (GDP) Per Capita has increased over time in nominal US dollar terms, many Nigerians, unfortunately, are still living in abject poverty despite the massive amount of human and material resources.

More worrisome is that, from 1960, when Nigeria became independent, to 2020, and with an average life span of 60 years, the country has experienced several ethno-religious and political crises of various degrees with attendant effects on the national security. For example,
Nigeria experienced severe political situation between 1960 and 1966, leading to the first and second military coups (Ojiako, 1979). The complications that arose from this unfortunate development led to the civil war between 1967 and 1970 (Adejo, 2008). Since the Second Republic, ethno-religious conflicts have continued to divide the country along ethnic and religious lines (Otite and Albert, 1999), this is coupled with insurgency and other criminal activities affecting the security of the country.

It is imperative to state that Nigeria's political arrangement has made interactions between ethnic groups, cultures, traditions, and religions very corrosive. This later resulted into ethnic, religious and political misunderstanding, mistrust, domination, conflicts and eventual crises. As a result, fear, suspicion, intolerance, grievances, greed and marginalisation have continued to define the relationships among most communities in the country (Tella, 2015). Furthermore, it has created fear of 
not getting one's fair share of scarce resources in the last 60 years of Nigeria as an independent State.

From the preceding, it is not out of point to state that Nigeria as a country, in the past 60 years, has been battling with all the aforementioned unhealthy phenomena, thereby creating security challenges, with attendant effects in the process of nation-building. It is on this note that this paper investigates the effects of ethno-religious conflicts on security in Taraba State, Nigeria, 1991 to 2020.

\section{A FOCUS ON KEY CONCEPTS}

Security is the key or compound concept in this paper. The concept itself has sub concepts: human security, personal security, community security, economic security, food security, health security, environmental security, political security and national security. For the purpose of clarity, these concepts will be examined operationally in this paper.

\section{Security}

Security is a fragile and significant issue which conveys different meanings to different people and organizations across the globe. The definitions of the concept vary according to the contexts and norms it is defined. It also has to do with individual societies based on specific standards, values and aspirations, a violation of any which is considered by such a society as insecurity.

Fundamentally, security has to do with the presence of peace, safety, gladness and the protection of human and physical resources or absence of crisis or threat to human dignity, all of which facilitate development and progress of any human society (Afolabi, 2015). The general understanding of the concept of security implies safety or the absence of threats to acquired societal values, life and property. It equally entails freedom from danger to life and property and the presence of a conducive atmosphere for the people to pursue their legitimate interests within the society. Buzan (1999) asserts that security is about freedom from threats and the ability of the government to maintain independent identity and their fundamental integrity against forces of change, which they see as hostile while its bottom line is survival.

Nwagboso (2012) asserts that security is the act of being safe from harm or danger, the defence, protection and preservation of values, and the absence of threats to acquired values. This means that security is about survival and the condition of human existence. Security also exists when people live together in a certain environment without disturbance or violence.

Security can also be viewed as freedom from danger or threats, and the ability of a nation to protect and develop itself, promote and cherish values and legitimate interests and enhance the well-being of its people (Adebakin, 2012).
This can be maintained through an internal security system, which usually, in any given society, is very important because, it is used to prevent violence and criminal activities. Internal security also ensures the freedom of people from any criminal disturbances. It guarantees the absence of criminal tendencies, undermines the nation's internal cohesion and cooperate existence and its ability to maintain its core values and meet the people's legitimate aspirations (Usman and Mathew, 2014).

In general terms, security is the act of guaranteeing the survival of all and sundry in the society. It searches to avoid, prevent, reduce, or resolve violence and conflict in any given community (Usman and Mathew, 2014). Therefore, general peace and security in any given society are associated with lack of violence, absence of civil disorder/disturbance and insurgency, to mention but a few. On the opposite, insecurity connotes different meanings: absence of safety, danger, hazard, uncertainty, lack of protection, and lack of security (Ewetan and Urhie, 2014).

Furthermore, insecurity is the state of being open or subject to danger or threat of danger, where danger is the condition of being susceptible to harm or injury. It is a state of being exposed to risk or anxiety, where anxiety is a vague unpleasant emotion experienced in anticipation of some misfortune (Acumba et al., 2013). Similarly, Ewetan and Urhie (2014) see insecurity as a breach of peace and security, whether historical, religious, ethno-religious, civil, social, economic or political, contributing to recurring conflicts, which leads to wanton destruction of lives and property.

From the preceding, security is about the feeling of being safe from harm, fear, anxiety, oppression, danger, and poverty. It is about defence, protection and preservation of core values and any threat to those values is considered insecurity. Therefore, to have a comprehensive understanding of what security broadly means, there is a need to incorporate specific essential components, which, put together, will give a more concise, but broad picture of what security implies. The specific essential components are as follows: Human security (with different dimensions), national and international security (Buzan, 1999).

\section{Human security}

The concept of human security emanates from the conventional security studies which center on the security of the state. It bothers mainly about the security of life of the individual or citizen, and its ultimate end-point is the protection of people from traditional and non-traditional threats (Afolabi, 2015). Watson (2011) and Kumse and Jones (2010) opine that human security has to do with all those attributes that enhance the people's peaceful environment and well-being devoid of threats to life, hunger, disease, crime, jobs, and so on. That is to say, the center point to human security is the belief that its 
deprivation can undercut peace and stability within and among states. Thus, the Commission on Human Security (CHS), in one of its works, defines human security as:

The ability to protect the vital core of all human lives in such a way that it enhances human freedom and human fulfilment. It means protecting fundamental freedom that are the essence of life. It means protecting people from serious and persistent threats and situations. It means using processes that build on people's strength and aspirations. It means creating political, social, environmental, economic, military and cultural systems that together gave people the building blocks of survival, livelihood and dignity (Adedoyin, 2013).

Based on the definition above, it is important to state that human security covers every aspect of human needs. It forms the basis of all forms and categories of security. Therefore, under human security, this paper places and conceptualizes below, other dimensions or components of human security.

Personal security: This is when individual and people are protected from physical violence either from within or outside the country. The violence could be from individuals, groups, sub-state actors or from domestic abuse. Therefore, the greater and common threat to personal security is from the state, groups of people, individuals or gangs. The security threats and risks on persons and, sometimes, families and communities are many and vary from place to place, and also from time to time. These include theft, armed robbery, burglary, food poisoning, electrocution, fire outbreak, home accident and a host of others (Afolabi, 2015: p. 6). Communal conflicts in Taraba State have affected personal security in many areas.

Community security: This is closely related to personal safety. It is a situation where the people are protected from the loss of traditional relationships, values and also safeguarded from sectarian and ethnic violence. About half of the world's states have experienced some interethnic rivalry. In Africa, many nation-states have witnessed ethnic clashes, land and boundary clashes, intra-religious and inter religious conflicts, all of which constitute threats (Afolabi, 2015: p. 5). Take note that threats to community security usually come within the group (oppressive practices), between groups (ethnic violence), or from dominant groups (e.g indigenous against settlers). This has also affected the people of Taraba State on several occasions.

Economic security: This is a situation whereby the basic income of the individual, mostly from productive and remunerative work, is assured. It equally connotes the absence of threats to the society's resources and a peaceful atmosphere for the people to engage in economic activities free from threats of any kind. The absence of this breeds economic insecurity with its major root causes as persistent poverty, unemployment, lack of access to credit and other economic opportunities (United Nations, 2016). In Nigeria, the above factors are causes and consequences of conflicts.

Food security: This entails that all people at all times have free access to basic food. Life cannot be secured without basic food. Therefore, food is the only means for the sustenance of life. Whenever there is hunger, famine, and sudden inflation of food prices, food insecurity is certain and applicable in most parts of Nigeria ravaged by conflicts.

Health security: This entails protection from diseases and unhealthy daily life. Afolabi (2015) notes that in both developing and developed countries, threats to health security are usually greater for poor people in local areas, particularly children. Health insecurity is caused by lack of access to primary health care, epidemic, natural disaster, insufficient or inadequate nutrition, lack of clean water and other basic necessities (United Nations, 2016). Towards the end of 2019, the whole world was plunged into health insecurity when coronavirus became a pandemic, and affected all sectors of global endeavours in 2020.

Environmental security: This connotes the safety of the environment to accommodate and provide necessary factors for the sustenance of life. The primary goal of this is to protect people from the short and long-term ravages of nature, man-made threats in nature and deterioration of the natural environment. While environmental degradation, natural disasters and resource depletion are general root causes of environmental insecurity worldwide (United Nations, 2016), lack of access to clean water resources is one of the greatest environmental threats in the third world countries (Afolabi, 2015: p. 6).

Political security: Among other considerations, the hallmark of political security is the absence of all manner of impediments in the political space for the free participation of citizens. This entails the guarantee and protection of fundamental human rights of the citizenry. It is concerned with whether people live in a society that honours their fundamental freedoms. Some of the threats attached to these are political or state repression, including torture, disappearance, human rights violations, detention and imprisonment. Afolabi, citing Amnesty International, asserts that, political repression, systematic torture, ill treatment, hostage taking and kidnapping are still being practiced in about 110 countries (Afolabi, 2015: p. 7). Human rights violations are frequent during periods of political unrest, and by security agencies in the third world countries (United Nations, 1994). In the case of Nigeria, violent conflicts have affected the fundamental rights of the 
citizens, including the rights to education and religion. From the preceding, it is not arguable to state that human security can exist at all levels of development. They can emerge slowly and silently or appear suddenly and dramatically. Central to human security is the idea that people have "the right to live in freedom and dignity, free from poverty and despair... with an equal opportunity to enjoy all their rights and fully develop their human potentials" (United Nations, 2012). Human security recognizes the interlinkages between peace, development and human rights, and equally considers civil, political, economic, social and cultural rights; thus, human security forms part of the family of human concepts, including human rights, human needs and human development (Gomez and Gasper, 2020).

\section{National security}

This is perceived in two major components, namely: internal and external security. While internal security has to do with the absence of domestic threats of all kinds, external security implies the absence of threats to territorial integrity perpetrated by external forces or factors. Thus, the concept of national security is perceived by scholars summarily as follows:

a) Ray (1987) sees it as the capacity for self-defence.

b) O'Brien (1995) summarizes the concepts as the absence of violence of all kinds as they affect a nation, be it military, environmental, economic, political, social, and so on.

c) Goldstein (1999) associates national security with the ability of a nation to defend its borders and territorial integrity from external forces; the power of a nation to its sovereignty; control of conflicts and threats to lives of citizens, among others.

From the foregoing, the main function of the state is to provide or promote human and national security. This entails the provision of those institutions or agencies specifically to provide safety for the citizens and to ensure equal access to the law and protection from abuse.

\section{International security}

International security, also referred to as Global security simply refers to the measures taken by states and international organizations, such as the United Nations, European Union, and others, to ensure mutual survival and safety. These measures include military actions and diplomatic agreements such as treaties and conventions (Wikipedia, 2021).

According to Osisanya (2021), global security evolved from the necessity that nature and other activities, particularly globalization, have placed on states.

\section{ETHNO-RELIGIOUS CONFLICTS IN TARABA STATE}

Taraba State is one of the 36 States of Nigeria. Its development could be contextualized and linked to the development of Nigeria since the attainment of independence in 1960 (Agbu et al., 2020a). The State is located in the North-Eastern region of Nigeria, it was carved out by General Ibrahim Babangida from the defunct Gongola State and became a State on 27th August, 1991 (Agbu, 2016).

The state is currently made of 16 Local Government Areas and 2 Special Development Areas, with over 80 ethnic groups having distinct historical and cultural heritage, and the dominant religious beliefs of the people are Christianity, Islam and African Traditional Religion (ATR) (Taraba State Government, 2020). Thus, Taraba State has diverse ethno-religious backgrounds, which is why Danjuma refers to it as a mini-Nigeria (Shibayan, 2018). However, instead of harnessing the socio-cultural diversities for positive benefits and development, the opposite is the case, particularly, ethno-religious conflicts which has continued to affect the security of the state and the nation at large.

According to Thompson (2017), ethnic and religious mobilization can often be found at the heart of political competition. As with all social cleavages, fault lines within societies formed along these identities create opposing interests. These differences of interest, in turn, offer themselves to potential or occasional violent conflicts.

Unfortunately, Taraba State has witnessed violent ethno-religious clashes across its three Senatorial Districts. These conflicts have claimed thousands of lives, displaced hundreds of thousands of others, and fostered a climate of instability through the surrounding areas (Ajibu, 2020) in addition to the destruction of property worth billions of Naira. Examples of these ethno-religious conflicts in Taraba State since her creation are reflected in the Table 1.

Table 1 revealed that Taraba State has experienced devastating religiously motivated and ethnic instigated violence, including farmers/herders inspired crises since creation. It is also vital to assert that these conflicts, which are motivated mainly by ethnic divide, tend to snowball into religious confrontation, thereby taking the forms of ethnoreligious conflicts.

\section{Overview of causes of ethno-religious conflicts in Taraba State}

According to Yuguda and Goni (2013), a major cause of ethno-religious conflicts in Nigeria is the accusations and allegations of neglect, oppression, domination, exploitation, victimization, discrimination, marginalization, nepotism and bigotry. This is because different groups and individuals have diverse interests, in which case, some groups will have their aims met, while others will not. In 
Table 1. Ethno-religious crises in Taraba State since 1991 to 2020.

\begin{tabular}{|c|c|c|c|c|c|c|}
\hline $\mathbf{S} / \mathbf{N}$ & Year & LGA/Place & $\begin{array}{l}\text { Nature of } \\
\text { Conflict }\end{array}$ & Parties Involved & Causes & Consequences \\
\hline 1 & $\begin{array}{l}1991 / 1992 \\
2001 / 2002\end{array}$ & $\begin{array}{l}\text { Wukari, Ibi \& } \\
\text { Gassol, LGAs. }\end{array}$ & Ethnic & Jukun \& Tiv & $\begin{array}{l}\text { Dispute over farm land \& } \\
\text { traditional/political positions. }\end{array}$ & $\begin{array}{l}\text { Loss of hundreds of lives \& property } \\
\text { worth millions of Naira destroyed. }\end{array}$ \\
\hline 2 & 1992 & Jalingo & Religious & Christians \& Muslims & $\begin{array}{l}\text { Crisis between Christian \& Muslim } \\
\text { students at GSSS Jalingo. }\end{array}$ & $\begin{array}{l}\text { Death of many \& destructions of } \\
\text { property, distrust among Christians } \\
\& \text { Muslims. }\end{array}$ \\
\hline 3 & 1992 & Ibi & Ethno-Religious & Jukun \& Hausa/Fulani & $\begin{array}{l}\text { Dispute over Nwonyo fishing festival of } \\
\text { March } 1992 .\end{array}$ & Destruction of lives \& property. \\
\hline 4 & 1996 & Karim Lamindo & Ethnic & Karimjo \& Fulani & Struggle over farming \& grazing land. & $\begin{array}{l}\text { Death of human-beings, animals \& } \\
\text { destruction of property, farmlands \& } \\
\text { homes. Internal displacement of } \\
\text { persons. }\end{array}$ \\
\hline 5 & $1997 / 1998$ & Karim Lamindo & Ethnic & Wurkum \& Fulani & Same as above. & $\begin{array}{l}\text { Death of human-beings, animals \& } \\
\text { destruction of property, farmlands \& } \\
\text { homes. Internal displacement of } \\
\text { persons. }\end{array}$ \\
\hline 6 & $1997 \& 2008$ & Takum \& Ussa & Ethnic & Kuteb \& Chamba & $\begin{array}{l}\text { Claim of ownership of Takum \& its } \\
\text { traditional stool; Takum LG } \\
\text { Chairmanship elections \& Kuchicheb } \\
\text { festival. }\end{array}$ & $\begin{array}{l}\text { Loss of hundreds of lives \& } \\
\text { destructions of millions of properties }\end{array}$ \\
\hline 7 & 1998 & Karim Lamindo & Ethnic & Wurkum \& Fulani & Same as between Karimjo \& Fulani. & Same as between Karimjo \& Fulani. \\
\hline 8 & $1999 / 2000$ & Wukari \& Ibi & Ethnic & Tiv \& Fulani & Struggle over farming \& grazing land. & $\begin{array}{l}\text { Death of human-beings, animals \& } \\
\text { destruction of property, homes. } \\
\text { Internal displacement of persons. }\end{array}$ \\
\hline 9 & $2002 \& 2017$ & $\begin{array}{l}\text { Sardauna/Mam } \\
\text { billa Plateau }\end{array}$ & Ethnic & Mambila \& Fulani & $\begin{array}{l}\text { Claim of ownership of Mambilla Plateau } \\
\& \text { its traditional stool; Claim over } \\
\text { ownership of land. }\end{array}$ & $\begin{array}{l}\text { Loss of hundreds of lives \& } \\
\text { destructions of millions of properties }\end{array}$ \\
\hline 10 & 2007 & Lau & Ethno-Religious & $\begin{array}{l}\text { Hausa/Fulani Muslims \& } \\
\text { Lau Christians }\end{array}$ & Dispute over farming \& grazing land. & $\begin{array}{l}\text { Death of human-beings, animals \& } \\
\text { destruction of property, farmlands \& } \\
\text { homes. Internal displacement of } \\
\text { persons. }\end{array}$ \\
\hline 11 & 2012 & Ussa & Ethnic & Kuteb \& Tiv & Dispute over farmland. & $\begin{array}{l}\text { Killing of people \& destruction of } \\
\text { farms. }\end{array}$ \\
\hline 12 & $2012-2015$ & Ibi & Ethno-Religious & $\begin{array}{l}\text { Jukun Christians \& } \\
\text { Hausa/Fulani Muslims }\end{array}$ & $\begin{array}{l}\text { Forceful penetration of a road-block } \\
\text { mounted in front of a Church (CRCN) } \\
\text { for security purpose. }\end{array}$ & $\begin{array}{l}\text { Death of many, destruction of } \\
\text { houses \& other property, IDPs. }\end{array}$ \\
\hline 13 & 2013-2015 & Gassol \& Bali & Ethnic & Fulani \& Tiv & Dispute over farming \& grazing land. & $\begin{array}{l}\text { Death of human-beings, animals \& } \\
\text { destruction of property, farmlands \& } \\
\text { homes. Internal displacement of } \\
\text { persons. }\end{array}$ \\
\hline
\end{tabular}


Table 1. Contd.

\begin{tabular}{|c|c|c|c|c|c|c|}
\hline 14 & 2013-2015 & Wukari \& Ibi & Ethnic & Jukun/Tiv \& Fulani & Dispute over farming \& grazing land. & $\begin{array}{l}\text { Death of human-beings, animals \& } \\
\text { destruction of property, farmlands \& } \\
\text { homes. Internal displacement of } \\
\text { persons. }\end{array}$ \\
\hline 15 & $2010 ; 2013-2015$ & Wukari & Ethno-Religious & $\begin{array}{l}\text { Jukun Christians \& Hausa } \\
\text { Muslims }\end{array}$ & $\begin{array}{l}\text { Intolerance between Jukun Christians \& } \\
\text { Jukun, Hausa Muslims. }\end{array}$ & $\begin{array}{l}\text { Death of many, destruction of } \\
\text { houses \& other property, IDPs. }\end{array}$ \\
\hline 16 & 2015 & $\begin{array}{l}\text { Ardo-Kola \& } \\
\text { Gassol }\end{array}$ & Ethnic & Fulani \& Mumuye & Forceful grazing on farm lands. & $\begin{array}{l}\text { Death of many \& destruction of } \\
\text { houses, farm produce \& animals. }\end{array}$ \\
\hline 17 & $2016 \& 2020$ & Lau & Ethnic & Shomo \& Joli & Dispute over fish ponds. & $\begin{array}{l}\text { Death of many \& destruction of } \\
\text { property \& houses. }\end{array}$ \\
\hline 18 & 2016 & Gashaka & Ethnic & Fulani \& Ndola & $\begin{array}{l}\text { Killing of Ndola woman on the farm by } \\
\text { Fulani herdsmen. }\end{array}$ & $\begin{array}{l}\text { Death of many, destruction of } \\
\text { houses, farmlands \& animals }\end{array}$ \\
\hline 19 & 2016 & Karim Lamindo & Ethnic & Shomo \& Wurkum & Reprisal attacks. & $\begin{array}{l}\text { Deaths of few, injuries and burning } \\
\text { of houses. }\end{array}$ \\
\hline 20 & 2017 & Ardo-Kola & Ethnic & Mumuye \& Jukun Kona & Politics. & $\begin{array}{l}\text { Death of many } \& \text { destruction of } \\
\text { houses leading to IDPs. }\end{array}$ \\
\hline 21 & 2018 & Lau & Ethno-Religious & $\begin{array}{l}\text { Hausa/Fulani \& } \\
\text { Yangdang/Kunini/Habe }\end{array}$ & Dispute over farming \& grazing lands. & $\begin{array}{l}\text { Deaths of several people, } \\
\text { destruction of property \& killing of } \\
\text { animals. }\end{array}$ \\
\hline 22 & 2018 & Takum \& Ussa & Ethnic & Fulani \& Jukun/Kuteb & As in the case between Tiv \& Fulani. & As in the case between Tiv \& Fulani. \\
\hline 23 & 2019 & Ardo-Kola & Ethnic & Fulani \& Jukun Kona & Forceful grazing on farm lands. & $\begin{array}{l}\text { Death of many \& destruction of } \\
\text { houses, farm produce \& animals. }\end{array}$ \\
\hline 24 & $2019 / 2020$ & $\begin{array}{l}\text { Wukari, Donga, } \\
\text { lbi, Takum, Bali } \\
\text { \& Gassol. }\end{array}$ & Ethnic & Jukun \& Tiv & $\begin{array}{l}\text { Same reasons as in 1991/92 \& } \\
2001 / 2002 \text {. }\end{array}$ & $\begin{array}{l}\text { Destruction of lives, property, } \\
\text { houses, farms \& trust. IDPs }\end{array}$ \\
\hline 25 & 2020 & Bali & Ethnic & Fulani \& Tiv & $\begin{array}{l}\text { Dispute over farming \& grazing land. } \\
\text { Displacement of people. }\end{array}$ & $\begin{array}{l}\text { Death of human-beings, animals \& } \\
\text { destruction of property, farmlands \& } \\
\text { homes. Internal displacement of } \\
\text { persons. }\end{array}$ \\
\hline 26 & 2020 & Jalingo & Religious & Christians \& Muslims & $\begin{array}{l}\text { Dispute over girlfriend between a } \\
\text { Christian \& Muslim youth. }\end{array}$ & $\begin{array}{l}\text { Burning of worship places \& houses; } \\
\text { death of } 2 \text { youths \& injury to many } \\
\text { people. }\end{array}$ \\
\hline
\end{tabular}

Source: Muhammad (2017). Unpublished Ph.D Thesis, \& Other Electronic, Print Media \& Published Materials, 2020/2021.

other words, these conflicts occur when deprived groups and individuals attempt to increase their share of power and wealth or to modify the dominant values, norms, beliefs or ideology (Yuguda and Goni, 2013).
The above points to the fact that there seems to be a divisive interplay of ethno-religious and political factors, which has consequently led to rising ethnic chauvinism, militancy and religious movements in the state. The overall consequence of this is the escalation of various ethno-religious conflicts, witnessed all-over Nigeria today, with Taraba State inclusive, which are meant to correct any perceived form of marginalization, oppression or domination. Nevertheless, with specific reference to ethno- 
religious conflicts in Taraba State, researches put forward specific causes in accordance with the nature of the conflicts. For instance, the Jukun-Tiv conflicts of 1990/92 and 2001/2002 were caused by several factors, including political manoeuvring and domination, claim over land ownership, and marginalisation. Also, mass migration, lack of respect for constituted traditional authority and indigene/settler dichotomy, among others were recorded as the underlying factors (Agbu et al., 2019). The Chamba and Kuteb conflicts of 1997 and 2008 in Takum LGA were caused by some factors, including political manipulation and contestation to the throne of the traditional ruler of Takum (Hassan and Akombo, 2012; Agbu and Ibrahim, 2018). The Mambila and Fulani conflicts of 2002 and 2017 were caused by claims to ownership of the Mambilla Plateau, traditional ruling power of the Mambilla Plateau and land issues (Edward and Abel, 2012). The conflicts involving Fulani herders and other ethnic groups (farmers) in Taraba State revolve around land for grazing and farming, cattle rustling, and criminality (Amnesty International, 2018).

Apart from the above crises in Taraba State, there have been cases of violence between the Fulani herders and local farmers in Takum, Ussa, Wukari, Lau, Sardauna, Gassol, Ibi, Bali, Ardo-Kola, Gashaka and Karim-Lamido LGAs, and other parts of the State over crop destruction by cattle, killing of herders, stabbing of farmers, following reprisal attacks on different occasions. Rukwe et al. (2019) further note that farmers-herders conflicts arose from an increase in competition over arable land use due to the rise in the population of both the farmers and herders. Other causes of the conflicts include: expansion of farmers on pastures, invasion of farmlands by cattle, assault on female farmers by herders, blockage of the stock routes and water points. Others include burning of range lands, cattle theft, changes in climate condition leading to drought and desert encroachment, and so on. Herders and local farmers' conflict is now happening with religious, tribal and cultural conflicts in Taraba State. This is because most farmers tend to be of the same ethnic groups and mostly Christians, while most herders are Fulani and mostly Muslims. In the event of a conflict between these groups, they are easily perceived as ethnic or religious conflicts because of their close association along such lines (Rukwe et al., 2019).

Between 1992 and 2015, series of conflicts occurred across Taraba State. In 1992, religious conflict broke out between Muslims and Christians in Jalingo and environs, leading to the loss of hundreds of lives, with Mosques and Churches set ablaze, and houses, shops and markets destroyed. The conflict resulted from a misunderstanding which started between Christian and Muslim students of Government Science Secondary School, Jalingo (Muhammad, 2017). Similarly, in that same year, 1992, Ibi town went on fire due to ethnic crisis between Jukun-Wanu and Hausa/Fulani Muslims (Akoga, 2012). Again, in 2012, twenty years after the 1992 episode, Ibi went on fire again in a religious crisis between the Christians and Muslims. This time around, the immediate cause was a forceful penetration of a roadblock mounted in front of a Church (CRC-N), for security purpose (Ajibu, 2020; Igidi, 2012). The crisis re-occurred occasionally between 2012 and 2014 , and was a remote factor in the Wukari religious conflicts of 2013 to 2015 (Zhema and Agbu, 2015).

Among the remote and immediate causes of the conflicts, particularly in Wukari, between the Christians and Muslims were: politics, attack on Police Area Command and commercial banks in 2010, indiscriminate roadblocks on prayer days, lbi crisis of 2012, illegal arrest of some Jukun youths by DSS in December, 2012, and the football field incident of February, 2013 (Zhema and Agbu, 2015). Thus, between 2013 and 2015, Wukari experienced devastating ethno-religious violence in six episodes; and also within that period, there were series of attacks on most Jukun farming communities in Wukari and Ibi LGAs by Fulani armed herdsmen.

Generally, therefore, this paper agrees with Muhammad (2017) that the factors responsible for ethno-religious conflicts and insecurity in Taraba State can be discussed under the following variables: ethnicity/ethnic identity, religious intolerance, fear of political/religious domination, government policy/local government creation and boundary demarcation, ignorance, poverty/unemployment and destructive publications by media houses, among others.

\section{The effects of ethno-religious conflicts on security in Taraba State and Nigeria at large}

In all the conflicts outlined, the effects were devastating the destruction of innumerable number of lives, burning of worship places, markets, schools, health facilities, security posts, commercial business institutions. The effects also include destruction of farms, farm produce and killing of cattle and other animals; injuries to numerous persons, creating the high number of widows and orphans; disruption of social and economic endeavours, causing social distrust; consolidation of poverty and unemployment. The conflicts created an incalculable number of Internally Displaced Persons (IDPs), and thus affecting the people's social, political and economic accomplishments. More importantly, the ethno-religious conflicts in Taraba State affected the security of not only Taraba State, but Nigeria at large.

Considering the number of ethno-religious conflicts experienced in Taraba State since her creation, it would be appropriate to assert that the security of the people and the state at large has become threatened by insecurity. However, for suitable presentation and understanding, this article examines the effects of the conflicts on security in Taraba State and Nigeria at large, under the various components of human and national security as follows: 


\section{Effects on personal and community security}

In all the ethno-religious conflicts experienced in Taraba State from 1991 to 2020, thousands of people (men, women, children and the aged) lost their lives and several others got injuries of various degrees (World Watch Research, 2015; Amnesty International, 2018). This has affected the personal security of the people of Taraba State and Nigeria at large.

On community security, closely related to death and injuries to people, ethno-religious conflicts in Taraba State also led to destructions of communities/settlements and destruction of traditional relationships and values. From the Mambilla to Lau and Karim-Lamindo; Ardo-Kola to Wukari and Ibi; Takum to Gassol and Bali LGAs, many communities and settlements were totally destroyed and burnt down completely, causing painful experiences on the people of Taraba State and other parts of Nigeria.

\section{Effects on economic and food security}

Ethno-religious conflicts in Taraba State have also affected the sources of livelihood of the people. Several people that survived the onslaught lost almost all their homes and means of survival. Many of them became internally displaced persons in their own land, suffering from abject poverty, while others became unemployed. All these affected the economic security of Taraba State and Nigeria at large (Alubo, 2006; Agbu et al., 2012; World Watch Research, 2015; Agbu et al., 2020b). In the same vein, several people were displaced during the Chamba/Jukun-Kuteb conflicts in Takum LGA; FulaniMambila conflicts in Sardauna LGA; Fulani-Jukun in ArdoKola LGA (Hassan and Akombo, 2012; Edward and Abel, 2012), among others.

Destruction of the people's means of livelihood, particularly agriculture, affected food production. The conflicts between farmers and herders; conflicts between farmers and farmers, greatly affected food production within the state and beyond (Alubo, 2006; World Watch Research, 2015; Rukwe et al., 2019; Oruonye et al., 2020). Herders-Farmers' conflicts did not only have a direct impact on the lives and livelihood of those involved, but also disrupted and threatened the sustainability of agricultural and animal production in the area and, invariably, the sustainability of livelihood of the farming households. The conflicts, no doubt, have negative impact on social and economic developments in not only Taraba State, but Nigeria at large, hence, affecting food production, causing food insecurity.

\section{Effects on health security}

The ethno-religious conflicts in Taraba State also have severe effects on health security. The conflicts did not only contribute to the destruction of communities and settlements, but also led to the destruction of basic infrastructures such as healthcare facilities, electricity and water sources (Adamu, 2002; World Watch Research, 2015; Muhammad, 2017; Okechukwu, 2017; Ojochenemi et al., 2017). More to the destruction of healthcare and water facilities, the conflicts led to rise in number of internally displaced persons (IDPs) who faced several challenges ranging from hunger, poverty, diseases, disrespect, rape, and other social challenges (Alubo, 2006; World Watch Research, 2015).

\section{Effects on environmental and human security}

Ethno-religious conflicts in Taraba State have also affected the safety of the physical environment to accommodate and provide necessary factors for the sustenance of life. It is on record that some of the violence were extended to natural resources in the areas. For instance, economic trees such as mango, orange and palm, among others, were cut down by the various militia groups as they attacked and destroyed communities (Danasabe, 2020). More to the destruction of economic trees, in some of the affected districts, bridges/culverts linking communities were destroyed, pits were dug across roads and water-ways blocked. At the same, wells were condemned by dumping dead bodies into them as the case with Kente, Akwana and Arufu in 1990/92 and 2001/2002 Tiv-Jukun conflicts (Alubo, 2006). All these atrocities affected the environment severely.

Also, during these conflicts, the fundamental human rights of the citizens were no longer guaranteed and protected. The types of human rights abuse in conflict situations vary from torture, rape, murder, child-labour and forced-labour to more recent cases of genocide, mutilations, ethnic cleansing and the use of refugees as human shield, including denial of people's rights to exercise their franchise (Sangosanya and Sha, 2005). The conflicts have also deepened political resentment amongst ethnic and religious groups in the state (Sangosanya and Sha, 2005).

The effects also extend to people's fundamental rights to religious worship and formal education. These rights were grossly infringed upon. Mosques and Churches were not only destroyed, but both Christian Clerics and, as well as adherents of the two religions, were killed. Similarly, both Christians and Muslims were denied their freedom to religious worship. In a similar vein, primary and secondary schools were destroyed, teachers were killed and pupils/students were denied their rights to formal education. Other effects include effects on relationship within and among groups and on image of Taraba State at national and international level.

At the level of inter and intra ethnic and group spheres, ethno-religious conflicts in Taraba State in particular; and Nigeria have weakened these spheres of relationships 
amongst individuals and groups in various communities.

The ethno-religious conflicts have placed Taraba State on a very negative side of national discourse. During these ethno-religious conflicts, sophisticated arms and other dangerous weapons were used freely by the actors on the perceived opponents. This affected the people of Taraba State, other passers-by, non-indigenes and foreigners who were residing in Taraba State or passing through the state (Danasabe, 2020). The report of these atrocities described Taraba State as a state with high rate of insecurity in Nigeria.

\section{CONCLUSION AND RECOMMENDATIONS}

This study investigated and revealed through the use of a table to assert that Taraba State experienced ethnoreligious conflicts in all the three Senatorial Zones, from the Jukun-Tiv ethnic conflicts in the Southern Zone to the Mambila-Fulani ethnic conflicts in the Central Zone, and the Hausa/Fulani-Yangdang/Kunini/Habe ethno-religious crisis in Northern Zone. These conflicts affected the state in all dimensions of human security - personal and community security, economic and food security, health security, environmental and human rights security.

Despite the plethora of security measures taken to address the daunting challenges caused by this violence nation-wide, and Taraba State in particular, government efforts have not produced the desired positive results, thus leading to the consolidation of other developmental challenges such as endemic rural and urban poverty, unemployment, inadequate physical and social infrastructure which are indices of insecurity. This meant that ethno-religious conflicts have severe effects on the security of Taraba State and the nation. Therefore, deliberate attempt must be made to put a stop on the incessant ethno-religious conflicts, not only in Taraba State, but Nigeria at large, otherwise, the clamour for unity and development will remain a myth, and insecurity would take-over the order of the day, as it has become, with devastating consequences on all and sundry.

For Taraba State in particular to minimize or be able to curtail incessant ethno-religious conflicts in the post-2020 era, in order to restore and consolidate security in the land, the following suggestions are made:

1. The people of Taraba State in particular, and Nigerians at large, should tolerate one another in their daily living, despite their ethnic and religious differences. They should accept each other, and permit their religious and ethnic practices even when they contradict each other's way of life, in order to live peacefully as one.

2. More so, the adherents of the two major religions in Taraba State (Christianity and Islam) should adhere to the teachings of the religions as enshrined in the Holy books. Both Christianity and Islam condemn violence in the strongest terms. This will foster mutual relations and peaceful co-existence among people, irrespective of their social, cultural and geographical differences.

3. The government at the federal, states and local levels should live up to their responsibilities of creating conducive environment for sustainable developments by ensuring that poverty and unemployment are reduced drastically and realistic social programmes are pursued and systematically implemented to ensure that the people meet their basic needs and the number of idle-minded youths are also reduced. This will improve the security of the state and the nation.

4. Government at all levels should be proactive in dealing with security issues and threats, through modern methods of intelligence gathering and sharing in order to prevent explosion of violence among the people.

5. Dialogue and Alternative Dispute Resolution (ADR) methods should be employed. Ethnic and religious leaders should be provided a platform with which they can, in unity, influence their subjects and followers on the need for respect, tolerance, peaceful coexistence and the avoidance of violence in conflict situation.

6. Communities, ethnic and religious leaders, including ethnic-biased politicians should put all sentiments behind them and strive to always expose criminals among their subjects/followers and supporters. This would go a long way in restoring the security of Taraba State and Nigeria at large.

7. In order to resolve the violence emerging from the conflicts between herders and farmers, which mostly snowballed into religious crises, there should be regular education and orientation of both the herders and farmers. The herders need to be educated more on the benefits of ranching and modernised animal farming.

8. Finally, the teaching of History as a subject in the secondary schools must be implemented with all seriousness, particularly in Taraba State. Through this, the secondary school students, who are considered leaders of tomorrow, would understand the diverse cultures of the many ethnic groups in Taraba State and Nigeria at large, and understand the likes and dislikes of these groups. This should be coupled with the teaching of both Christian and Islamic Religious Studies to all students in the primary and secondary schools, irrespective of their religious differences. Once this is implemented, Nigeria, in the next two decades, will become a peaceful nation from where other nations of the world would borrow ideas from in order to live in peace, harmony and security.

\section{CONFLICT OF INTERESTS}

The authors declare that they have no conflict of interests.

\section{REFERENCES}

Acumba, I. C., Ighomereho, O. S., \& Akpan-Robaro, M. O. M. (2013). Security challenges in Nigeria and implications for 
business activities and sustainable development. Journal of Economics and Sustainable Development, 4(2), 79-99.

Adamu, D. A. (2002). Issues in Tiv-Jukun conflict, Jos: Target Publicity.

Adebakin, M. A. (2012). National security challenges and sustainable economic development. Evidence from Nigeria, 1(1), 10-20.

Adedoyin, A. (2013). An appraisal of the multidimensional nature of security in the post-cold war Africa. African Journal of Stability and Development, 7(2), 113-130.

Adejo, A. M. (2008). (Ed.) The Nigerian civil war: forty years after, what lesson. Makurdi: Aboki Publishers.

Afolabi, M. B. (2015). Concept of Security. In: Ajayi, K. (ed.) Readings in intelligence and security studies. Intelligence and Security Studies Programme, Afe Babalola University, Ado Ekiti.

Agbu, A. D. (2016). A brief history of Taraba State University, 2008-2016. Jos: Jema Printers \& Publishers.

Agbu, A. D., Mohammed, I., \& Joseph, M. P. (2020a. The political development of Taraba State, 1991-2019. Wukari International Studies Journal, 1(1), 20-38.

Agbu, A. D., Zhema, S., \& Agbu, R. S. (2020b). An investigative study into the causes and effects of ethno-religious conflicts on women and children in Wukari and lbi local government areas of Taraba State, Nigeria, 1991-2020. International Journal of Sociology and Anthropology Research, 6(3), 121-140.

Agbu, A. D., Zhema, S., \& Tsojon, Y. I. (2012). Poverty, youth unemployment and criminality in north-eastern Nigeria: Threats to national development. Maiduguri Journal of Historical Studies, 1(1\&2), 105-133.

Agbu, A. D., Zhema, S., \& Useini, B. (2019). Jukun-Tiv relations in the Benue Valley region: The 2019 scuffles in southern Taraba State, Nigeria. International Journal of African Society, Cultures and Traditions, 8(1), 1-20.

Agbu, D. A., \& Ibrahim, I.G. (2018). The peoples of southern Taraba area: A study of inter-group relations, 1800-2013. Taraba State University, Jalingo, Maiden Research Bulletin, 1(1), 148-185.

Agbu, D. A., Anuye, S. P., \& Nyajo, M. D. (2017). Conflicts and integration of Nigeria from independence to 2015. Jalingo Journal of African Studies, 6(1\&2), 388-394.

Ajibu, I. M. (2020). Ethno-religious conflicts and impact on women and children in southern Taraba State: A case of Ibi and Wukari local government areas, 1991-2015. PGD, Project, Institute for Peace Studies \& Conflict Management, Taraba State University, Jalingo.

Akoga, N. B. (2012). Apa-Jukun history in the Benue valley: A portrait of socio-political history of Ibi from the 19th to 21st century. Makurdi: Oracle Business Ltd.

Alubo, O. (2006). Ethnic conflict and citizenship crises in the central region. University of Ibadan: PEFS.

Amnesty International (2018). Harvest of death: Three years of bloody clashes between farmers and herders in Nigeria. Nigeria: Amnesty International Ltd.

Buzan, B. (1999). New pattern of global security in twenty-first century. In: International Affairs. Royal Institute of International Affairs. Pp. 431-451.

Danasabe, D. (2020). Oral interview at Wukari, Taraba State.

Edward, L. N., \& Abel, J. (2012). Ethnicity and citizenship crisis in Nigeria: Interrogating inter-ethnic relations in Sardauna local government area, Taraba State. African Journal of Political Science and International Relations, 6(3), 48-61.

Ewetan, O. O., \& Urhie, E. (2014). Insecurity and socio-economic development in Nigeria. Journal of Sustainable Development
Studies, 5(1), 40-63.

Goldstein, J. (1999). International relations, New York: Addison Wesley, Longman.

Gomez, O. A., \& Gasper, D. (2020). Human security. UNDP report.

Hassan, E. L., \& Akombo, E. T. (2012). Ethnic violence in Southern Taraba and security challenges in the north-east region of Nigeria: The case of the Tiv-Jukun and KutebChamba conflicts. Paper presented at zonal conference, Historical Society of Nigeria, north-east zone, TSU Jalingo.

Igidi, T. (2012, Nov 24). Ibi Crisis ignites sorrow, tears and blood. Daily Trust. Retrieved from www.dailytrust.com.ng

Kumse, A., \& Jones, J. F. (2010). Climate change and human security in Africa. International Journal of Sustainable Development and World Ecology, 17(6), 453-461.

Muhammad, B. A. (2017). Ethno-religious conflicts and insecurity in Taraba State, Nigeria: Islamic perspective, a panacea. Unpublished Ph.D Thesis, Department of Islamic Studies, University of Bakht Al-Ruda, Sudan.

Nwagboso, C. I. (2012). Security challenges and economy of the Nigerian State (2007-2011). American International Journal of Contemporary Research, 2(6), 244-258.

O'Brien, R. (1995). International political economy and international relations: Apprentice or teacher? London: John MacMillan.

Ojiako, J. O. (1979). 13 years of military rule. Lagos: Daily Times Publishers.

Ojochenemi, A. P., Amayll, J. L., \& Ogwuche, J. (2017). Effects of ethno-religious crises on the infrastructure of Wukari town, Taraba State, Nigeria. International Journal of Emerging Trends in Social Sciences, 1(1), 22-28.

Okechukwu, O. K. (2017). The effects of inter-communal conflicts in Nigeria, The case of Takum local government area, Taraba State. Journal of Education Research and Behavioural Science, 6(4), 059-065.

Oruonye, E. D., Ahmed, Y. M., \& Fatima, A. Y. (2020). Impact of farmers and herders conflict on food security in Nigeria: A case study of Taraba State, Nigeria. Scholars Journal of Arts, Humanities and Social Sciences, 8(3), 154-163.

Osisanya, S. (2021). National security versus global security. United Nations. Retrieved 17th June, 2021 from https://www.un.org/en/chronicle/article/national-securityversus-global-security.

Otite, O., \& Albert, I. O. (1999). (Eds.) Community conflicts in Nigeria: Management, resolution and transformation. Ibadan: Spectrum Books Ltd.

Oyeniyi, B. A. (2012). Political narratives as historical realities: Is Jos conflict an ethno-religious conflict? In: Albert, I.O. (ed.). A history of social conflict and conflict management in Nigeria (pp. 35-51). Ibadan: John Archers.

Ray, J. (1987). Global politics. (3rd edition). Boston: Houghton Mifflin.

Rukwe, D. T., Abdullahi, Y. M., Farouk, A. U., \& Nwaeze, U. (2019). Effects of farmers-herders conflict on farming households in southern Taraba State, Nigeria. South Asian Research Journal of Agriculture and Fisheries, 1(3), 106-111.

Sangosanya, J. A., \& Sha, D. P. (2005). Ethno-religious conflicts and human rights violations in Nigeria. Jos: Christian Foundation for Social Justice \& Equity.

Shibayan, D. (2018, March 24). Danjuma asks Nigerians to defend themselves against killers, 'says armed forces not neutral'. Sahara Reporter. Retrieved from www.sahara.net.

Taraba State Government (2020). Taraba State Government 2020 Executive Diary. 
Tella, C. M. (2015). Insecurity in northern Nigeria: Causes, consequences and resolutions. International Journal of Peace and Conflict Studies, 2(4), 23-36.

Thompson, A. (2007). Introduction to African politics. (2nd edition), New York: Routledge.

United Nations (1994). United Nations Development Programme Report.

United Nations (2012). General Assembly, 66th Session.

United Nations (2016). Human Security Handbook.

Usman, I. C., \& Mathew, D. A. (2014). Security challenges in Nigeria and national transformation. International Journal of Managerial Studies \& Research, 2(8), 8-16.

Watson, S. (2011). The human as referent object? Humanitarinism as securitazation. Security Dialogue, 42(1), 3-20.

Worldometer (2021). Nigeria population forecast. Worldometer. Retrieved 10th June, 2021 from https://www.worldometers. info/world-population/population-by-country/
World Watch Research (2015). Violent conflicts in divided societies: The case study of violent conflict in Taraba State, (2013-2015). Abuja: Nigeria Conflict and Security Analysis Network (NCSAN) Working Paper 2.

Yuguda, M. A., \& Goni, I. (2013). Ethno-religious conflict in Taraba State and its implications on socio-economic, political and educational development of youths. International Journal of Social Sciences \& Humanities Review, 4(3), 149-155.

Zhema, S., \& Agbu, A. D. (2015). The Jukun of the Benue valley: Interrogating the nexus between intergroup history and conflicts, 2013-2014. In: Ukaogu, V. (ed.). United in differences, disunited in agreement: Analysis of people, traditions, culture and endless conflicts amongst the Jukun of central Nigeria (pp. 283-290). Abuja: Academic Press Ltd. 